\title{
Political-Legal Order and the Curious Double Character of China's Courts
}

\author{
Ling LI* \\ University of Vienna
}

\begin{abstract}
This article provides an analytical account of how politics and law in China are organically integrated in the institutional architecture of courts as designed by the Chinese Communist Party ("the Party"). This design allows the Party to retain its supreme authority in the interpretation, application, and enforcement of the law through its institutional control over courts. At the same time, the Party can, under this design, also afford to grant an autonomous sphere where courts can perform their adjudicative functions with minimal interference from the Party, as long as the Party is assured of full authority to determine the scope of the "autonomous-zone," to impose rules on it, and to revoke it when necessary. Consequently, courts assume a double character: a pliant political agent on the one hand and a legal institution of its own agency on the other.
\end{abstract}

Keywords: Chinese Communist Party (CCP), China's courts, political-legal committee, judicial politics, rule by law, judicial independence

\section{INTRODUCTION}

In the modern world in which we live today, few legal systems are riddled with contradiction as overtly as China's, where its ruling Party, the Chinese Communist Party (CCP, "the Party"), proclaims to "rule according to the law" while the courts pledge to subject themselves to the leadership of the Party. Such contradiction is not merely a matter of sound logic, but also an issue of political consequence. As courts are required to serve two masters - the Party and the law-it is only natural for discerning legal practitioners to ask which master the courts should serve first. The Party rebutted this line of questioning by contending that to place the Party and the law at opposite ends is a false proposition. ${ }^{1}$ Instead, a synergy was suggested between the Party and the law in a complementary relationship where the Party is considered the only able and reliable guardian of the rule of law. ${ }^{2}$ Such a proposition is propagated in

* Correspondence to Ling Li, Department of East Asian Studies/Sinology, University of Vienna, Spitalgasse 2, Hof 2, Tür 2.3, Vienna, 1090, Austria. E-mail address: liling6234@gmail.com. The author has written extensively on Chinese politics and law, especially issues related to corruption and anti-corruption. Her most recent publication can be found at https://univie.academia.edu/LingLi.

1. See in the selected excerpts of Xi Jinping's public speeches and writings available at http://politics.people.com. $\mathrm{cn} / \mathrm{n} / 2014 / 1028 / \mathrm{c} 1001-25926332 . \mathrm{html}$.

2. Zhu (2010). 
Party discourses, culminating in the public statement recently made by Xu Xianming, a wellknown constitutional legal expert and deputy-president of the Supreme People's Procuratorate (SPP). In addressing a gathering of lawyers at a Rule of Law Forum, Xu said: "The Party is in the law, under the law and above the law [at once]." 3 Not surprisingly, this state of organic integration of politics and law, as Xu described above, is also reflected in the modern Chinese legal lexicon, where the words “politics 政” and "law 法” are coined together into a single compound word "politics-law 政法" that is used to characterize the nature of all institutions that deal with law and order, including the judiciary, law, and enforcement agencies as well as educational and training institutions of legal professionals.

Among experts and observers of China's legal development, this built-in political character of China's judiciary is widely acknowledged and seldom disputed. However, at the same time, recent studies show that, despite the many political constraints confronting them, courts also demonstrate considerable autonomy at both national and local levels. For the national level, Taisu Zhang made a cogent argument that the Supreme People's Court (SPC) is propelled not by the Party, but by its own interests to pursuit legal reforms that would strengthen its own position and status in the sociopolitical structure in which it operates. ${ }^{4}$ This non-political space for judicial autonomy exists also, if not more so, at the local level, since the majority of cases processed by these courts are non-political, low-stake, mundane disputes that do not concern the interest of the Party. ${ }^{5}$ In addition, local courts are also found to be embedded in a complex ecosystem that is defined not only by political, but also administrative, economic, and social factors. ${ }^{6}$ The matrix of these various dimensions of "embeddedness," as documented in $\mathrm{Ng}$ and He's extensive account of day-to-day judicial decision-making in China, seems to have somehow obscured the political character of these courts. How can this spacious non-political field that courts work on be understood and reconciled with the rigid image described earlier in this section, where politics and law are organically integrated?

In this article, I intend to answer this question by examining the Party-state structure in which courts are embedded, the development of the political-legal apparatus of the Party, their functions, operational mechanisms, and ramifications. Specifically, I will first trace the historical development of the political-legal order that determines the political character of courts in Section 2. Next, I will provide a chronological account of the evolution of specialized supervisory bodies of the Party that have been put in charge of routine monitoring of court activities. In Section 3, I will explain the mechanisms through which the Party manages its control of judicial activities, thereby embedding courts in the overall political structure of the Party-state.

\section{POLITICAL-LEGAL ORDER}

When the CCP took over power from the Kuomintang Party (KMT) in 1949, it introduced the Common Program (gongtong gangling) as a transitional constitution. According to the

\footnotetext{
3. A transcript of Xu Xianming's speech is available at http://www.sohu.com/a/134315960_570256.

4. Zhang (2012).

5. Fu \& Peerenboom (2010).

6. $\mathrm{Ng} \& \mathrm{He}$ (2017); Li (2017).
} 
Common Program, which has strong Soviet influence, the state power resided in the Central (coalition) Government, members of which were to be elected by the National People's Congress (NPC). ${ }^{7}$ Once elected, the Central Government would become the highest state decision-making body ${ }^{8}$ - humongous institution under which were the executive branch, namely the State Council, the SPC, and the SPP. ${ }^{9}$ In practice, since the Central Government was only an executive assembly with no implementation and enforcement infrastructure and resources, it had to delegate most of its decision-making power to the State Council. The SPC and the SPP, despite its independent status vis-à-vis the executive branch endowed in the Common Program, were in practices supervised by the Political-Legal Committee of the State Council-a mandate given personally by Mao Zedong, the chairman of the Central Government, and Zhou Enlai, the premier of the State Council. ${ }^{10}$ This means that the State Council were exercising de facto the executive, judicial, and prosecutorial power, as well as, to some extent, legislative power.

This institutional structure had significantly augmented the power of the State Council and simultaneously slowed down, if not blocked, the information flow from various state institutions to Mao, who chaired both the Central Party Committee and Central Government Committee. Mao considered such operation "bureaucratic" and having impaired his ability to oversee and control the development of important state affairs. ${ }^{11}$ After the incident of Gao Gang and Rao Shushi (the most serious political crisis that the Party had experienced then since 1949), ${ }^{12}$ Mao headed off to Hangzhou to supervise the drafting of the first People's Republic of China (PRC) Constitution. ${ }^{13}$ The new Constitution was promulgated in 1954, which flattened the state structure. It dissolved the "super" state institution, the Central Government, which only had nominal power, and separated state power among four branches: the legislature, the executive, the judiciary, and the prosecution. At the same time, the Constitution also installed a measure of "supervised checks and balances" among the four branches of the state. The legislature was the highest decision-making body of the state. ${ }^{14}$ It was to elect the head of government and to make laws. ${ }^{15}$ The State Council was to administer state affairs according to the law. ${ }^{16}$ Courts were to adjudicate disputes according to the law. ${ }^{17}$ The Procuratorate was to inspect any violation of laws by state institutions and individual citizens. $^{18}$

\footnotetext{
7. Kavass \& Christian (1979).

8. Art. 12 of the Common Program.

9. Zhongyang renmin zhengfu zuzhi fa [Organizational Law of the Central People's Government] (1949), Art. 15.

10. Liu (2013), p. 5.

11. Ibid., pp. 7, 10-11.

12. Gao was accused of campaigning during 1952-53, with Rao's collaboration, for the seat of vice-chairman of the PRC and premier of the State Council, in defiance of the Party's rule on prohibition against electoral campaign. Their activities were characterized by the Party as conspiratorial and anti-party. The incident was considered to be the most threatening challenge to the unity of the Party since 1949; see zhonggong zhongyang guanyu Gao Gang, Rao Shushi fandang lianmeng de jueyi [Central Party's Decision on the Anti-Party Alliance of Gao Gang and Rao Shushi] passed by the National Party Delegates' Conference in 1955.

13. $\operatorname{Li}(2016)$.

14. PRC Constitution (1954), Art. 21.

15. Ibid., Art. 31.

16. Ibid., Arts 43, 47.

17. Ibid., Art. 73.

18. Ibid., Art. 81.
} 
The same Constitution also introduced the concept of "judicial independence" in Article 78, which stipulated that: courts exercise judicial power independently and only answer to the law. Of course, like many other provisions in the Constitution, Article 78 had never been actualized. When the Constitution was amended in 1982, Article 78 was replaced by Article 126, which stipulated: "Courts are to exercise judicial power independently and free from interference from the executive branch of the government, social organizations and individuals." In the revised definition, the Party organization, which is not a branch of the government or social organization or individual, is curiously left out of the list from which courts are supposed to be independent. At the same time, not surprisingly, the provision that "courts only answer to law" was deleted.

Constricting judicial independence to the supremacy of the Party vis-à-vis the state has many ramifications in terms of judicial authority and court administration. The first and most obvious is that courts cannot scrutinize activities of the Party. Instead, Party activities are subject to self-regulation from top-down. ${ }^{19}$ The second is that the capacity of a court to command compliance from a subject of court, either being an institution or individual, is constricted by the power relation between the court and that subject involved. The Party determines and administers a rank order that embodies the chain of command, which is essential for the authoritarian rule of the Party over the state. Every state institution is assigned a rank, including courts. The scope of authority of any given court over a subject is commensurate to that subject's rank vis-à-vis the court. In other words, courts can command compliance by institutions and individuals of lower or no rank, but not by those of equal or higher ranks or those who can draw influence from the former, unless the Party authorizes it. By subjecting courts to this rank order, the Party can maintain its supreme authority over judicial authority. This relative nature of judicial power also explains why China's courts can be on the one hand too powerful, capable of corrupt and even predatory conduct, extracting resources from litigants with no political status or influence, ${ }^{20}$ and on the other hand completely deplete of power, shunning, as frequently seen, cases that are brought by litigants against powerful institutions and individuals. ${ }^{21}$

At the same time, this severely constrained version of judicial independence, which is later termed as “adjudicative independence 审判独立” to best avoid semantic confusion with "judicial independence,"22 makes the Party's engagement in judicial affairs indispensable in two aspects. First, being the only institution that has authority over both courts and other state institutions, the Party has acquired a privileged position that allows it to break the checks and balances and align actions of various state institutions to maximize the efficiency and effectiveness of implementation of prioritized Party policies. Second, since courts cannot command compliance by institutions of equal or higher ranks, they have to frequently engage the Party to provide solutions for disputes between courts and other such state institutions, as well as to marshal resources and command compliance by other state institutions so that courts can perform their judicial activities. Frequent demands for such actions had made it necessary for the Party to establish specialized Party apparatus to handle these issues on a

\footnotetext{
19. Party Charter (2012), Chapter 2.

20. $\operatorname{Li}(2012)$.

21. He (2007).

22. Anonymous (2017).
} 
routine basis. The next section will explain the institutional development of this specialized Party apparatus, which is, however, not a linear process. As will be shown, these institutions had gone through cycles of disbandment, resurrection, and reshuffling and became more stabilized only after 1990 .

\section{POLITICAL-LEGAL SUPERVISORY BODIES}

In this section, I provide a brief introduction of the historical development of various Party decision-making bodies that were established to supervise political-legal matters. Such an overview will help us to understand the analysis of the operation of current supervisory framework that will follow. First of all, a clarification of the nomenclature is needed. In China, collective references of law-related institutions can be somewhat confusing. It is therefore necessary to first clarify relevant nomenclature that will appear below. In this article, I use the term "Party political-legal apparatus" as a reference of specialized Party institutions that are established to conduct routine supervision of the so-called "politicallegal institutions." These "political-legal institutions (zhengfa jiguan)" refer to state institutions $^{23}$ that perform law-related functions, typically including courts, the police, the procuratorates, the Ministry of Justice but not the legislature, namely people's congresses. ${ }^{24}$

The institutional development of the Party political-legal apparatus since 1949 has been a process of constant shifts, in terms of its names, structures, and functions. As shown in Table 1, the first Party political-legal apparatus was the party-group nested under the State Council Political-Legal Committee established in $1949 .{ }^{25}$ Strictly speaking, the party-group is not a "party institution," but only an "outpost" dispatched by a Party institution to represent the Party's interest in the committee. The committee's mandate included: to steer, arrange, check, and inspect the work of the ministries of civil affairs, justice, and public security. In addition, since the state was in its infancy, the State Council Political-Legal Committee was also mandated to set up state agencies and perform some civil services, such as providing veteran benefits and relief. ${ }^{26}$ Then, in 1954, the Constitution separated the legislative, executive, prosecutorial, and judicial powers. Under the new Party-state structure (explained in the previous section), to have a committee under the State Council to co-ordinate political-legal affairs became inappropriate. Thus, the State Council PoliticalLegal Committee was dissolved. In its place, the Party established the Central Party Legal Committee under the Central Party Committee. The Central Party Legal Committee was mandated to undertake assignments of the Central Party Committee, to review Party principles and policies on legal affairs, to review (institutional arrangements and activities) regarding the division of labour, and checks and balances between political-legal

23. For an explanation about the significance of the distinction between Party institutions and state institutions, see Li (2015).

24. People's congresses have higher standing in the state structure, at least nominally. They are usually referred to as "legislative institutions (lifa jiguan)" and not included as a member of the "political-legal institutions." Military courts of the People's Liberation Army and the Para-Military Police are also members of the "political-legal institutions" but their involvement in ordinary judicial and law-enforcement activities is evidently limited compared with other institutions listed in the main text.

25. Zhongyang renmin zhengfu zuzhi fa [Organizational Law of the Central People's Government] (1949), Art. 18.

26. Hou (2013), p. 3. 
Table 1. List of names of Party supervisory bodies on political-legal matters at the national level since 1949

\begin{tabular}{|c|c|}
\hline 1949-54 & State Council Political-Legal Committee Party-Group \\
\hline 1954-58 & Central Party Legal Committee \\
\hline 1958-78 & $\begin{array}{l}\text { Central Party Political-Legal Small Group (with periods of suspension during the } 1960 \mathrm{~s} \\
\text { to 1970s) (CPPP-LSG) }\end{array}$ \\
\hline 1978-88 & Central Party Political-Legal Committee (CPPLC) \\
\hline 1988-89 & Central Party Political-Legal Leading Small Group (CPPL-LSG) \\
\hline $\begin{array}{l}\text { 1989- } \\
\text { present }\end{array}$ & Central Party Political-Legal Committee (CPPLC) \\
\hline $\begin{array}{l}\text { 2003- } \\
\text { present }\end{array}$ & Central Party Judicial Institutional Reform Leading Small Group (CPJIR-LSG) \\
\hline
\end{tabular}

institutions. ${ }^{27}$ Meanwhile, the SPC, SPP, and the Ministry of Public Security (MPS) continued to report directly to the Central Party Committee through the party-groups installed in these institutions. ${ }^{28}$

In May 1958, Mao reshuffled the Politburo and the Central Party Secretariat at the 5th Plenum of the 8th Party Central Committee. ${ }^{29}$ Immediately afterwards, the Central Party Political-Legal Small Group (CPPL-LSG) was established, replacing the Central Party Legal Committee. This Small Group, along with four other Central Small Groups, was expected "to bring issues that were previously discussed within the State Council directly to the Central Party Secretariat for discussion." ${ }^{30}$ Mao was particularly emphatic on this point, making the following remarks in a drafted notice of the establishment of the small groups: "These Small Groups belong to the Central Party, immediately subject to and shall report directly to the Politburo and the Central Party Secretariat ... [The Party-state] only has one institution for political design, not two." 31

The leader of the first CPPL-LSG was Peng Zhen, a Politburo member at the time of appointment. Other members included leaders of the MPS, the SPC, the SPP, and a deputy prime minister. ${ }^{32}$ In 1959, the CPPL-LSG expanded to include a few deputy leaders of each of the state political-legal institutions. ${ }^{33}$ During the late 1950s and throughout the 1960s, as the political struggle within the Party intensified, the focus of the CPPL-LSG was dominated by anti-revolutionary class struggles. At the same time, political-legal work departments were gradually established in Party institutions of most provinces and major cities, to co-ordinate and inspect political-judicial activities on behalf of the provincial or prefectural Party committees. $^{34}$

During the Cultural Revolution, as the Party institution was dismantled, the Central Political-Legal Small Group also stopped functioning. ${ }^{35}$ The entire state legal system

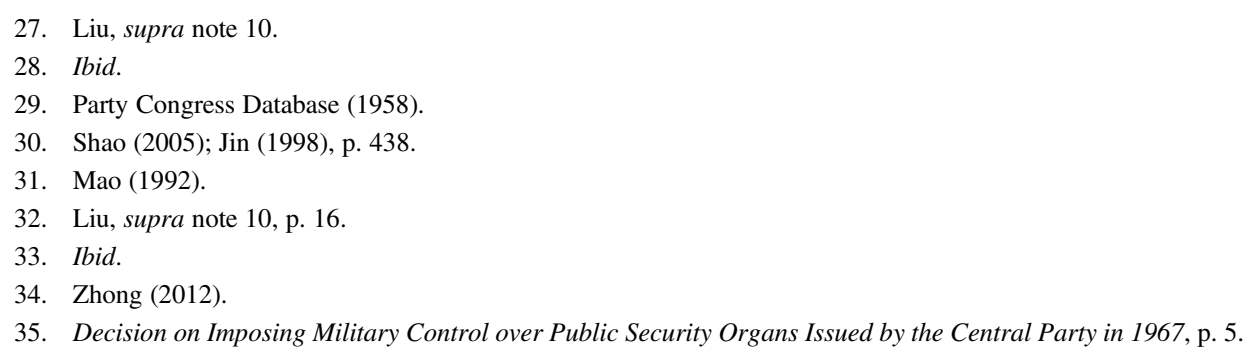


remained paralyzed until the end of the Cultural Revolution, when court activities were gradually restored. ${ }^{36}$ In June 1978, the CPPL-LSG was re-established to assist the Central Party with inspecting the SPC, SPP, MPS, and the Ministry of Civil Affairs' activities. ${ }^{37}$ The new CPPL-LSG only existed for a few months before it was replaced yet again by the now well-known Central Party Political-Legal Committee (CPPLC) after the 3rd Plenum of 1978.

According to the CPPLC's first director, Peng Zhen, the role of the CPPLC is threefold. First, it is the Central Party's "consultant" and is to conduct research, provide opinions, and propose plans for the Party on law-related issues. ${ }^{38}$ Second, it is the Central Party's "organizational agent," with a mandate to marshal various legal institutions, with "unified understanding, unified action, mutual coordination and concerted action," in order to implement decisions made by the Central Party. ${ }^{39}$ Third, it is the Central Party's secretarythat is, it must carry out tasks assigned by the Central Party. ${ }^{40}$ Peng Zhen stressed that the Party Political-Legal Committee (PPLC), as an assistant to the Party Committee, is not a firstlevel (of independent standing) Party organization and its power should not be too broad. ${ }^{41}$

During the 1980s, as the political order was restored and economic reform started, the CPPLC was designated a permanent division of the Party, required to report and answer to the Central Party. It was authorized to conduct the following activities:

[The CPPLC] shall, under the leadership of the Central Party, to examine and handle important issues that have emerged in national political-legal affairs and provide advisory opinions to the Central Party; to assist the Central Party to handle the requests and reports submitted by various legal institutions to the Central Party for instructions, to coordinate all legal institutions, according to the principles, policies and instructions issued by the Central Party, so as to unify action, unify strategic planning and unify implementation regarding common and overarching issues that concern all legal institutions; to conduct research and survey regarding the status of implementation of Party principles, policies and state laws and regulations; to conduct research and investigation regarding the state of organizational affairs and thoughts of political-legal staff; to perform other assignments from the Central Party. ${ }^{42}$

The notice made it clear that the power of the CPPLC is derived from the authorization from the Central Party Committee. In other words, the Central Party Committee remains the highest decision-making body on, inter alia, judicial affairs, not the CPPLC. To avoid confusion, the Notice [1980] provided: "after the establishment of the CPPLC, each national [state] political-legal institution shall continue to report to the Central Party, State Council and the Central Military Committee."43 This was reiterated in the Central Party Instruction regarding the Enhancement of Political-Legal Work (1982): Party-secretaries

\footnotetext{
36. Yang (2013).

37. Liu, supra note 10.

38. Peng (1992b).

39. Ibid.

40. Ibid.

41. Liu, supra note 10, p. 20; see also Liu (2010F), p. 306.

42. Zhonggong zhongyang guanyu chengli zhengfa weiyuanhui de tongzhi [Central Party's Notice on the Establishment of Political-Legal Committee] issued in 1980.
}

43. Ibid. 
of Party committees shall personally check political-legal work and the party-secretaries of PPLCs shall refer important issues to Party committees for collective decisionmaking. ${ }^{44}$

Throughout the 1980s, the PPLCs nationwide mostly engaged in anti-crime "strike-hard" campaigns, where cases were processed swiftly with procedural protections frequently neglected and heavy sentences applied to the accused. ${ }^{45}$ Meanwhile, as the Party launched economic reforms, the concomitant reform to separate the Party and the state was also expedited. In 1988, at the height of the reforms, the Party decided to downsize the Party administration and dissolve Party departments and divisions that have corresponding state institutions that perform the same regulatory functions. The CPPLC was disbanded for a short time in 1988 and replaced by the Central Party Political-Legal Leading Small Group (CPPL-LSG), led by the newly elected Politburo Standing Committee member, Qiao Shi. ${ }^{46}$

The CPPL-LSG was one of about a dozen central leading small groups that bourgeoned since the 1980s. ${ }^{47}$ The central leading small groups deliberate national policies at the highest level and yet they have no status in the Party Charter. Almost all central leading small groups are led by members of the Politburo Standing Committee and have become the highest authorities for their respective regulatory sectors. ${ }^{48}$ Other members of these central leading small groups are drawn from key Party and state institutions that undertake corresponding regulatory responsibilities. ${ }^{49}$ At the inception of the CPPL-LSG, Secretary Qiao Shi, its director, stressed that the replacement of the CPPLC with the CPPL-LSG shall not be understood as the relaxation of the Party's control over political-legal affairs, but a change of the Party's governing approach. ${ }^{50}$ According to Qiao, some Party leaders had been too busy interfering with the operation of judicial institutions and some too timid to claim authority. ${ }^{51}$ Qiao criticized both approaches and stated that both should be rectified. ${ }^{52}$ However, the life of the CPPL-LSG was cut short by the political turmoil in 1989. After the Party had reinstalled political order, the CPPL-LSG was dissolved and the CPPLC was resurrected. Qiao Shi continued to act as the CPPLC's director.

Under Qiao Shi's leadership, the CPPLC was positioned "to steer and coordinate politicallegal affairs in a macro manner." Following the principle of the Party-state separation that survived the 1989 political crisis, PPLCs were required not to "over-interfere with the details of the work of legal institutions ... in order to ensure that courts and procuratorates can exercise their power independently." 53 In the 1990s, the CPPLC experienced its greatest institutional expansion as it was merged with the Central Social Security Comprehensive

44. Zhonggong zhongyang guanyu jiaqiang zhengfa gongzuo de zhishi [Central Party's Instruction on Enhancing the Political-Legal Work] issued on 13 January 1982.

45. Cui (2012).

46. Central Bianzhi Office (2011); Qian (2012); Special Report (2014).

47. State Commission Office for Public Sector Reform; also see Miller (2008).

48. Ibid.

49. Shao, supra note 30 .

50. Anonymous (2015); also see Chen (2012).

51. Chen, supra note 50 .

52. Ibid.

53. Zhonggong zhongyang guanyu weihu shehui wending jiaqiang zhengfa gongzuo de tongzhi [Central Party's Notice on Reserving Social Stability and Enhancing Political-Legal Work] issued on 2 April 1990. 
Management Committee (zhongyang shehui zhian zonghe zhili weiyuanhui). ${ }^{54}$ At the same time, the CPPLC was structurally strengthened and became a self-contained component of the Party apparatus, with offices established in local Party institutions from the provincial down to county levels. Heads of these local PPLCs have since then been granted memberships in local Party standing committees. ${ }^{55}$

The last and the latest Party political-legal apparatus is the Central Party Judicial Institutional Reform Leading Small Group (CPJIR-LSG), established in 2003, led by Luo Gan, a member of the Politburo Standing Committee. Zhou Yongkang succeeded Luo in 2007 and then retired in 2012. Compared with the CPPLC, whose primary function is to co-ordinate and conduct routine inspection over political-legal institutions, the CPJIR-LSG enjoys the highest decision-making authority on policies related to administration of justice. Unlike the CPPLC, whose mandates are limited to courts and other law-enforcement institutions, the CPJIR-LSG drew its members from a much wider range of institutions including the CPPLC, the SPC, the SPP, the MPS, the Legal Affair Office of the State Council, the Central Party Bianzhi ${ }^{56}$ Commission Office (which is involved in administering the ranking system), and the Internal-Affairs Committee of the NPC. ${ }^{57}$ Its authority extends far beyond "co-ordination" between the political-legal institutions, but also the co-ordination between politicallegal institutions with other state institutions, including the legislature, treasury, and personnel regulatory authorities. ${ }^{58}$

During their respective terms, Luo and Zhou each held leadership positions in both the CPPLC and the CPJIR-LSG. In 2012, when the once-in-a-decade power transition in the Party was scheduled, an unexpected chain of events led to the downfall of Zhou Yongkang, who was later expelled from the Party and sentenced to life imprisonment for abuse of power and corruption. ${ }^{59}$ In the wake of the scandal, the Party terminated the fusion of the leaderships of the CPPLC and the CPJIR-LSG. The Politburo Standing Committee was downsized, eliminating the seat that was previously allocated for the mandate of the CPPLC, which means the CPPLC leader can no longer enjoy a seat in the Politburo Standing Committee. At the same time, the CPJIR-LSG has remained active, directly supervised by the Party General Secretary and currently leading the most extensive judicial institutional reform since the judicial system was restored in the early 1980s.

\section{POLITICAL-LEGAL SUPERVISION}

China's courts are subject to political-legal supervision from the Party, usually via the PPLC, in two aspects. The first concerns judicial policies and general affairs and the second concerns judicial outcomes of specific cases.

54. Zhonggong zhongyang zhengfa weiyuanhui guanyu jiaqiang geji dangwei zhengfa weiyuanhui gongzuo de tongzhi [Central Party's Notice on Enhaning the Work of Party Committee Political-Legal Committee of All Levels] issued in 1995.

55. Ibid.

56. For more on the topic of bianzhi, see Brødsgaard (2002).

57. Qin (2014).

58. Xinhua News (2012).

59. $\operatorname{Lim}(2014)$. 


\subsection{Judicial Policies and General Affairs}

Here, judicial policies refer to those rules that regulate judicial activities and are issued by courts under instructions of the Party. The line between what qualifies as judicial policies and what qualifies as legislative matters is never clearly drawn. Since judicial policy-making is not bound by the deliberation, public participation, and voting procedures that are mandatory for the legislative process, judicial policies are issued with more flexibility. Such policies may appear in the form of judicial interpretation (sifa jieshi), opinion (yijian), decision (jueding), or notice (tongzhi). ${ }^{60}$ Even though these policies could have an ad hoc nature and may change as the leadership or the preference of the leadership shifts, they have a significant impact on the exercise of judicial power because of their immediate effect upon day-to-day court activities.

\subsubsection{Dictatorial Aspect}

The Party selectively engages in judicial policy-making either upon its own initiative or upon requests from courts and/or other state institutions. The Party is likely to take initiatives and instruct courts to issue certain judicial polices when the Party considers such policies would help solve certain prioritized matters. For example, in 1998, the Central Party launched a campaign against foreign currency purchase fraud as an effort to eradicate smuggling and to enhance the Central Government's regulatory capacity over economic activities. ${ }^{61}$ Following the Party's initiative, the NPC Standing Committee first amended the Criminal Code and criminalized foreign currency purchase based on false documentation and unauthorized trade of foreign currency. ${ }^{62}$ The SPC followed suit and issued a judicial policy, which reaffirmed the criminalization of the targeted conduct and clarified issues concerning the application of the amended law. ${ }^{63}$

Local Party institutions are also entitled to engage in judicial policy-making within their territorial jurisdictions. For example, in 2003, the Beijing PPLC issued a policy that authorized procuratorates to withdraw prosecutions and courts to exempt criminal punishment regarding misdemeanour offenders if the offender had shown remorse, provided retribution to the victim(s), and was forgiven by the victim(s). ${ }^{64}$ Similarly, the Chongqing PPLC had been holding annual meetings and issuing criminal judicial policies on both substantive and procedural matters, such as the factual threshold for prosecution regarding specific offences, the labelling of offences according to available evidence, sentencing guidelines for certain offences, interpretation of the legal definition of identified crimes,

60. The SPC has been frequently criticized by the NPC for encroaching legislative power by its law-making activities through issuance of judicial interpretations. Urged by the NPC, in 2012, the SPC identified 1,600 pieces of judicial interpretations (about half of the total number of judicial interpretations that the SPC has issued) for review and decided to revoke 715 of them. For a report on this project and related criticism of the SPC, see Yu (2013).

61. Anonymous (1998).

62. Quanguo renda changweihui guanyu chengzhi piangou waihui, taohui he feifa maima waihui fanzui de jueding [National People's Congress Decision on Punishing and Regulating Crimes of Faudulent Purchase of Foreign Currency, Illegal Deposit, Sale or Transfer of Foreign Currencies and Illegal Trading of Foreign Currencies] issued in 1998 .

63. Guanyu shenli piangou waihui, feifa maimai waihui xingshi anjian juti yingyong falv ruogan wenti de jieshi [Judicial Interpretation on Adjudicating Criminal Cases involving Fraudulent Purchase of Foreign Curriences and Illegal Depositing, Selling and Transferring Foreign Currencies] issued by the SPC on 28 August 1998.

64. Ye (2014). 
protocols regarding evidence collection, transfer of detainees, submission of application to interrogate or interview suspects, and protocols on access to case-files. ${ }^{65}$

When the Party engages in judicial policy-making, such activities often take place in conferences and meetings, hosted by PPLCs. Individual Party leaders can also make oral or written instructions (known as zhishi or pishi) within their authority and demand courts to develop policies in identified areas. For example, between 2010 and 2011, upon the receipt of pishi from Central Party leaders on dealing with widely reported food-safety scandals, the SPC issued a series of notices urging courts nationwide to increase the severity of punishment to food-safety-regulation violations. ${ }^{66}$ In 2013, the Central Party further prioritized food-safety regulation and shifted its focus from simply punishing violators to enhancing regulatory capacity. ${ }^{67}$ Concurrently, the SPC issued a judicial policy addressing food/drugsafety issues by enhancing the protection of consumers' rights and imposing stricter liabilities to food/drug manufacturers, sellers, and food/drug-safety regulators. ${ }^{68}$

When the Party takes initiatives to make judicial policies, it very often engages not only courts, but also other state institutions whose activities will be affected. This is particularly common for policies concerning criminal law, since criminal cases involve activities of at least two other state institutions: procuratorates and the police. For example, during the aforementioned campaign against foreign currency purchase fraud, the Party summoned the SPC, the SPP, and the MPS to meet together and to concert their actions in order to achieve the optimal outcome for the campaign. ${ }^{69}$ The co-ordination resulted in a decision, which covered issues ranging from jurisdictional disputes between the procuratorates and the public security bureaus, interpretation of the definition of the crime, to sentencing policies. ${ }^{70}$ Once issued, the decision was circulated to courts, procuratorates, and public security bureaus nationwide for implementation. ${ }^{71}$ More recent examples are the guiding opinion (zhidao yijian) issued by the CPPLC in 2013 and 2014, respectively, one concerning prevention of wrongful convictions and the other concerning judicial examination of applications for sentence reduction and parole. Following the Party's initiative, the SPC, the SPP, and the MPS all issued corresponding policies, translating the CPPLC's opinions into concrete operational procedures of their own, which were then circulated to courts, procuratorates, and public security bureaus nationwide. ${ }^{72}$

65. Conducted during the Chongqingshi zhengfa bumen wuzhang lianxi huiyi jiyao [Memo of the Joint Meeting of the Chiefs from the Five Political-Legal Institutions of Chongqing City].

66. The report only indicated that actions were taken to implement "central leader(s)' pishi" and did not identify the name(s) of leader(s) who sent the instructions; see Anonymous (2011).

67. Ma (2013).

68. Guanyu shenli shipin yaopin jiufen anjian shiyong falv ruogan wenti de guiding [Rules on Application of Laws in Cases Related to Food and Drugs Disputes] issued by the SPC on 9 December 2013.

69. Banli pianhui, taohui fanzui anjian lianxi huiyi jiyao [Memo on the Joint Conference on the Handling of Cases involving Fraudulent Purchase of Foreign Curriences and Illegal Depositing, Selling and Transferring Foreign Currencies] issued by the SPC, SPP, and MPS in 1999.

70. Ibid.

71. Guanyu yinfa banli pianhui, taohui fanzui anjian lianxi huiyi jiyao de tongzhi [Notice on the Dissemination of the Memo on the Joint Conference on the Handling of Cases involving Fraudulent Purchase of Foreign Curriences and Illegal Depositing, Selling and Transferring Foreign Currencies] issued by the SPC, SPP, and MPS in 1999.

72. Guanyu jianli jianquan fangfan xingshi yuanjiacuoan gongzuo jizhi de yijian [Opinions on the Establishment and Completing the Operating Mechanism to Prevent Wrongful Convictions] issued by the SPC in 2013; Guanyu qieshi lvxing jiancha zhineng fangzhi he jiuzheng yuanjia cuoan de ruogan yijian [Several Opinions on Truthfully Performing the Prosecutorial Duty to Prevent and Rectify False Convictions] issued by the SPP in 2013; Guanyu jinyibu jiaqiang he 
In the examples mentioned above, the Party exercised its policy-making power by giving courts more or less clear guidelines for policy development. On other occasions, the Party has provided very general and broad outlines and left it to courts to flesh them out. For example, in 2006, the Central Party made "Constructing Harmonious Society" as the thematic principle for the governance of the Party-state. The SPC subsequently developed a series of judicial policies, translating the abstract Party lines into operational judicial practices, including the well-known policy of balanced sentencing in criminal cases based on the nature and the totality of circumstances of the specific case concerned ${ }^{73}$ and the widely criticized policy that prioritized mediation over adjudication. ${ }^{74}$

\subsubsection{Paternal Aspect}

The Party's engagement in judicial policy-making is not only dictatorial. Because of its superior status, the Party also acts as a paternalistic arbiter, solving disputes and coordinating demands and interests of various state institutions in implementing and enforcing the law. For example, when the Criminal Procedural Law was promulgated in 1997, it caused controversy between courts and procuratorates regarding the staging of courtrooms and rules on court decorum. ${ }^{75}$ Specifically, courts and procuratorates disagreed on the height of the judges' bench vis-à-vis that of the prosecutors' desk. ${ }^{76}$ Disagreement also persisted regarding whether prosecutors should stand up, the same as the defendants and defence attorneys are required to do, upon judges' entrance to courtrooms. ${ }^{77}$ These issues were not as trivial as they may appear to be, since procuratorates took the value of symbolism seriously and argued that they enjoyed the same rank as courts and hence should not be subjugated to the authority of courts. ${ }^{78}$ The controversy was eventually arbitrated by the CPPLC, which decided that all parties, including the prosecutors, should remain seated upon entrance of judges and all should stand up when the judge announced court judgment—a symbolic act to manifest the authority and reverence of the law of the state. ${ }^{79}$ The CPPLC also "ruled" that

(F'note continued)

gaijin xingshi zhifa ban'an gongzuo qieshi fangzhi fasheng yuanjia cuoan de tongzhi [Notice on Further Strengthening and Improving Criminal Enforcement Activities and Reliably Preventing Wrong Cases] issued by the MPS in 2013; Guanyu jianxing, jiashi anjian shenli chengxu de guiding [Rules on the Adjudicative Procedure Regarding Reduction of Sentences and Paroles] issued by the SPC in 2014; Sifabu yaoqiu jinyibu guifan jianyu jianxing, jiashi, zhanyu jianwai zhixing gongzuo [Ministry of Justice Requiring Justice Administrations Further Strengthening the Regulation of Prisons on Sentence Reduction, Parole and Conditionally Serving Sentence Out of Prison] issued by the Ministry of Justice in 2014; Notice on Forwarding the Central Party Political-Legal Committee's Opinion on Strengthening the Regulation on Reduction of Sentence, Parole and Conditionally Serving Sentence Out of Prison and Reliably Preventing Judicial Corruption issued by Xiang Yang City Justice Bureau in 2014; Central Party Political-Legal Committee Issued Guiding Opinion on Strengthening the Regulation on Reduction of Sentence, Parole and Conditionally Serving Sentence Out of Prison to Enhance Judicial and Enforcement Credibility issued by the SPC in 2014.

73. Guanyu guanche kuanyan xiangji xingshi zhengce de ruogan yijian [Opinions on Implementing the Policy to Balance Leniency and Rigidity in Criminal Cases] issued by the SPC in 2010.

74. For example, see Minzner (2011).

75. Zhonggong zhongyang zhengfawei guanyu shishi xiugai hou de xingshi susongfa jige wenti de tongzhi [Central Party Political-Legal Committee's Notice on A Number of Issues Regarding the Implementation of the Amendment of the Criminal Procedure Law] issued in 1997.

76. Ibid.

77. Ibid.

78. Long (1997).

79. Zhonggong zhongyang zhengfawei guanyu shishi xiugai hou de xingshi susongfa jige wenti de tongzhi [Central Party Political-Legal Committee's Notice on A Number of Issues Regarding the Implementation of the Amendment of the Criminal Procedure Law] issued in 1997. 
judges' benches should be placed in the middle of courtrooms and could be placed on a raised podium on the grounds that an elevated bench would ensure that all participants have a clear view of the judges, who are the centre of courts' activities after all. ${ }^{80}$

Other than arbitrating disputes over courtroom furniture placement and decorum, the Party's paternalistic role is more evident when it lends support to courts when the latter need to secure resources and obtain co-operation or compliance from other state institutions that are beyond the reach of courts. In 1999, the SPC submitted a report to the Central Party complaining about other state situation's non-compliance with court orders. ${ }^{81}$ In particular, courts have been facing great difficulties in enforcing court judgments in civil and commercial cases because courts have no authority to compel compliance or co-operation from equally ranked state agencies that hold assets or information of the assets that courts are pursuing. ${ }^{82}$ These agencies include various asset registration agencies, residents' registration agencies, business registration agencies, banks, and tax and other financial regulators. ${ }^{83}$

The Central Party acknowledged the problem but did not raise the authority of courts and command compliance from other state institutions. Instead, it only circulated the SPC report to relevant institutions. ${ }^{84}$ The circular produced limited effect. In the years that followed, the SPC continued to seek support from various Party authorities. ${ }^{85}$ In 2010, the SPC announced an opinion signed by 19 Party and state institutions and agencies, including the Central Party Discipline and Inspection Committee (CCDI), the Central Party Organizational Department (COD), and the Central Propaganda Department (CPD). The opinion calls for the establishment of "a liaison and mobilization mechanism for court enforcement" at every administrative level. ${ }^{86}$ In the opinion, both the CCDI and COD agreed to investigate disciplinable conduct that involves obstruction and interference of court enforcement efforts if information concerning such conduct are collected during their routine work. ${ }^{87}$ The CPD agreed to publicize non-compliance conduct on official media and all other agencies agreed in principle to provide assistance and share information with courts for the purpose of asset recovery and forfeiture. ${ }^{88}$ The SPC congratulated itself on the issuance of this opinion and considered it a big step forward in solving the enforcement problems. ${ }^{89}$ However, none of these measures would overcome the structural constraints that shackle the authority of courts - the commanding authority over state institutions is preserved exclusively for the Party. Therefore, under the new framework, courts still need to seek support from various Party

80. Ibid.

81. Zhonggong zhongyang guanyu zhuanfa zhonggong zuigao renmin fayuan dangzu guanyu jiejue renmin fayuan zhixingnan wenti de baogao de tongzhi [Notice on the Forwarding of the Supreme People's Court Party-Group's Report on Solving the Problem of Enforcement Difficulties] issued by the Central Party in 1999.

82. Ibid.

83. Ibid.

84. Ibid.

85. Liu (2010W).

86. Guanyu jianli he wanshan zhixing liandong jizhi ruogan wenti de yijian [Opinions on Establishing and Completing the Joint Action Mechanism for Court Judgement Enforcement] jointly issued by the SPC and other 19 central institutions in 2010.

87. Ibid.

88. Ibid.

89. Ibid. 
authorities on a case-by-case basis (similarly to before), except that now they have a "gentleman's agreement" with a non-binding commitment of assistance and collaboration.

To conclude, the Party has reserved the power to make judicial policies whenever necessary so that the Party can ensure that court activities reflect political objectives and priorities of the Party. Compared with the legislative process (which the Party also supervises), regulating judicial activities through judicial policy-making is more convenient, efficient, and flexible. However, to reserve the judicial policy-making power alone is not sufficient to secure control over judicial affairs. It is because policies are not specific enough to inform courts what kind of judicial outcome the Party would expect in specific cases, especially cases of great political significance for which the Party cannot leave any room of discretion to courts. After all, the Party cannot foresee and determine in advance every circumstance that requires its dictation. Hence, the "micro" approach is also developed.

\subsection{Judicial Outcomes in Specific Cases}

The second aspect of political-legal supervision concerns the Party's entitlement and ability to control the outcomes of individual cases whenever it sees necessary through its secured direct access to judicial decision-making. In the Party's early history, dictating judicial outcomes had been an inherent feature of judicial practices. In Party-controlled borderregions during the 1930s, all court decisions on criminal cases had to be approved by Party committees before being issued. ${ }^{90}$ Such "case-approval" practice continued to dominate court activities even after the establishment of the PRC in 1949..$^{91}$ At times, the police, procuratorate, and courts worked jointly together, led by the Party, on high-profile cases. The practice was called "joint case-handling," where all these institutions would formulate investigative, prosecutorial, and adjudicative plans together towards the intended judicial outcome. ${ }^{92}$ Enjoying the efficiency generated by the practice of joint case-handling, Peng Zhen, the head of the then-CPPL-LSG, explained: "The practice of joint case-handling is not only possible but truly necessary. [For] so many cases [that we have], if you do your part, I do my part, without face-to-face communication and deliberation, how can it work?" ${ }^{93}$ In various periods of time in the 1950s, the SPC, the SPP, the MPS, and the Ministry of Justice (MOJ) were even merged into one as the result of government downsizing. ${ }^{94}$

After the Cultural Revolution, the Party issued the well-known No.64 Document that terminated case-approval practice. ${ }^{95}$ It means that courts no longer need to obtain approval from the Party for every case. However, the Party retained the power to supervise certain categories of cases that are of greater interest to it. The Party exercises this power mainly through one of two procedures: case co-ordination and case supervision. In theory, case coordination is a procedure by which various political-legal institutions can work together so as

90. Liu (2012).

91. Zhou (2012).

92. Hou, supra note 26, p. 4.

93. Peng (1992a).

94. Hou, supra note 26.

95. Guanyu jianjue baozheng xingfa xingshi susongfa qieshi shishi de zhishi [Instructions on Firmly Guarantee the Reliable Implementation of the Criminal Law and the Criminal Procedure Law] issued by the Central Party in 1979. 
to remove the "gridlock" that is likely to prevent a case from being closed timely and/or fairly. ${ }^{96}$ According to local PPLC regulations, ${ }^{97}$ cases that are typically eligible for coordination include: (1) cases that may result in delay or unfair decision because they involve jurisdictional disputes (between different but equal state agencies), disagreements on the facts of a case, characterization of the alleged offence or application of law; (2) cases that have jurisdiction-wide impact upon political social stability and economic development and hence require collaborated efforts from various state institutions; (3) new cases for which one cannot find clear rules in current laws, regulations, and policies; (4) other cases that the PPLC considers necessary for co-ordination. The Party can decide to "co-ordinate" a case on its own initiative or upon requests by courts or other institutions.

For cases marked for co-ordination, the PPLC is entitled to summon responsible institutions and officials who are handling the case to report to the PPLC and attend co-ordination meetings. ${ }^{98}$ Once consensus is reached, it will be formulated as a PPLC opinion, which will then be disseminated in the form of a memo to relevant institutions for implementation. ${ }^{99}$ Instructions sent by the Party to courts are outcome-oriented and supported by no legal reasoning. Sometimes such instructions have the exact terms of the expected verdict specified. For example, in a handful of cases involving selling tobacco without a licence, the Hubei Qianjiang PPLC instructed the court (through case co-ordination) that all defendants should be sentenced prison terms without probation. ${ }^{100}$ Sometimes, the intended outcome is camouflaged with politically correct slogans, such as "handle the case with caution according to the law." 101 The obligation to interpret the true intention of such instruction lies in whoever is expected to implement the instruction. ${ }^{102}$ In either scenario, courts are explicitly required NOT to cite Party instructions in their decisions as the source of authority for those decisions, ${ }^{103}$ presumably to remove concrete evidence of the Party's dictating role in judicial decision-making.

In addition to case co-ordination, the Party can also shape or influence the judicial outcome of a specific case through the case-inspection procedure, which is distinguished from case co-ordination in theory but often meshed with the latter in practice. Unlike case co-ordination (which is primarily used to overcome the "checks and balances"), case

96. Hongyang zhengfawei ganyu dangwei Zhengfa Weiyuanhui Dui Zhengfa Bumen Zhifa Huodong Jinxing Jiandu De shishi xize [Operational Manual on Party Political-Legal Committees' Supervisory Activities over Law Enforcement Activities of Political-Legal Institutions] issued by Qinghai Province PPLC in 2012; Guanyu dangwei Zhengfa Weiyuanhui Dui Zhengfa Bumen Zhifa Huodong Jinxing Jiandu De guiding [Rules on Party Political-Legal Committees' Supervisory Activities over Law Enforcement Activities of Political-Legal Institutions] jointly issued in 2011 by the CPPLC, CCDI, COD, and central political-legal institutions.

97. Tongren shi zhengfawei anjian xietiao ducha gongzuo shixing banfa [Provisionary Rules on Case Cordination and Inspection Work] issued by Tongren City PPLC; Zhonggong Zhangjiagang shi zhengfa weiyuanhui zhifa jiandu gongzuo shishi banfa [Operational Rules on Supervision over Law Enforcement] issued by Zhangjiagang City PPLC in 2010; Hunan sheng zhengfawei anjian duban xietiao gongzuo zhidu [Rules on Case Supervision and Coordination] issued by the Hunan Province PPLC.

98. See sources cited ibid.

99. Ibid.

100. Ye, supra note 64

101. Li, supra note 20.

102. Ibid.

103. Hunan sheng zhengfawei anjian duban xietiao gongzuo zhidu [Rules on Case Supervision and Coordination] issued by Hunan Provice PPLC; Renmin fayuan susong wenshu lijuan guidang banfa [Measures on Filing and Archiving Judicial Documents] jointly issued by the SPC and National Archives Bureau in 1991. 
inspection is designed primarily to investigate and solve complaints about non-compliance with Party policies and state laws. Cases that are eligible for inspection include cases concerning preservation of social stability or state security, cases having significant (political and social) impact, cases having caused litigants to resort to petition and having caused strong public reaction, high-profile cases that can potentially cause serious (political or social) problems, and cases involving unlawful conduct of political-legal officials.

The same as with "case co-ordination," a PPLC may invoke a case-inspection procedure either on its own initiative or upon requests from two channels. ${ }^{104}$ One channel is bottom-up, namely from Party institutions of the same or lower level. Requests from this channel are limited to cases with significant political, social, or economic implication. ${ }^{105}$ The other channel is top-down, namely from higher Party institutions or leaders. A higher Party authority can mark any case and sends it to a PPLC for inspection. ${ }^{106}$ To carry out a caseinspection procedure, the PPLC may instruct the responsible political-legal institution(s) that handle(s) the marked case to report its work progress to the PPLC within designated period of time. Such a report shall reflect the responsible institution's opinions on the evidence, facts, procedural issues, and application of law, and should also include its preliminary decision of the case. ${ }^{107}$ If the responsible institution could not close the case within the designated time, then it is required to provide reasons for the delay. After examination of the reasons provided, the PPLC can decide whether to extend the deadline. If the responsible institution continues to fail to meet the deadline or implement the specific opinion instructed by the PPLC, the PPLC shall propose a solution to the Party Committee and the higher PPLC. ${ }^{108}$ Measures of sanctions include public denouncement, revoke of qualification for performance award (including financial reward), suspension and transfer, official Party or administrative disciplinary sanction, and dismissal of responsible individuals. ${ }^{109}$

Unlike the Party's engagement in judicial policy-making (the macro approach), which has been accepted by most Chinese legal academics and practitioners as part of the constitutional reality of the Party-state, the Party's engagement in judicial decision-making in individual cases (the micro approach) has, however, caused increasing public concern. Such concern

104. Zhonggong huludao shi lianshan quwei zhengfawei zhifa jiandu gongzuo guize [Rules on Supervision over Law Enforcement] issued by Huludao City Lianshan District PPLC in 2011; Tongren shi zhengfawei anjian xietiao ducha gongzuo shixing banfa [Provisionary Rules on Case Cordination and Inspection Work] issued by Tongren City PPLC; Zhonggong Zhangjiagang shi zhengfa weiyuanhui zhifa jiandu gongzuo shishi banfa [Operational Rules on Supervision over Law Enforcement] issued by Zhangjiagang City PPLC in 2010; Hunan sheng zhengfawei anjian duban xietiao gongzuo zhidu [Rules on Case Supervision and Coordination] issued by Hunan Provice PPLC; Guanyu dangwei Zhengfa Weiyuanhui Dui Zhengfa Bumen Zhifa Huodong Jinxing Jiandu De guiding [Rules on Party Political-Legal Committees' Supervisory Activities over Law Enforcement Activities of Political-Legal Institutions] jointly issued by the CPPLC, CCDI, COD, and central political-legal institutions in 2011; Zhongyang zhengfawei ganyu dangwei Zhengfa Weiyuanhui Dui Zhengfa Bumen Zhifa Huodong Jinxing Jiandu De shishi xize [Operational Manual on Party PoliticalLegal Committees' Supervisory Activities over Law Enforcement Activities of Political-Legal Institutions] issued by Qinghai Province PPLC in 2012; Yongzhou shi lengshuitan qu dangwei zhengfa weiyuanhui anjian duban xietiao gongzuo zhidu [Rules on Case Supervision and Coordination] issued by the Yongzhou City Lengshuitan District PPLC in 2011.

105. See sources cited ibid.

106. Ibid

107. Ibid.

108. Ibid.

109. Zhonggong huludao shi lianshan quwei zhengfawei zhifa jiandu gongzuo guize [Rules on Supervision over Law Enforcement] issued by Huludao City Lianshan District PPLC in 2011. 
was heightened when a number of wrongful conviction cases were exposed in the 2000s. ${ }^{110}$ These cases shared a common feature: innocent defendants were accused and convicted for murder by courts under the "co-ordination" of local PPLCs. ${ }^{111}$ Exposure of these cases had led to heated public discussion and criticism against the PPLC's interference in the judicial decision-making process, which was blamed for having seriously discredited the judicial system and worsened the public distrust of courts because of prevalent judicial corruption. ${ }^{112}$

Under public pressure, the CPPLC formulated a series of measures to limit and regulate activities of local PPLCs. Such measures included: (1) demanding local PPLCs not to issue opinions regarding the "determination of the nature of an offense or [other] substantive issues of [individual] cases"113 and (2) declaring the following types of cases or issues not suitable for co-ordination: cases or issues for which the law or judicial interpretations have clear instructions or cases that should be resolved through legislation or judicial interpretation; requests that are not submitted through the proper channel; cases that have already been decided by a superior authority ${ }^{114}$; and cases that are not supported by clear facts or sufficient evidence. ${ }^{115}$ In 2013, the CPPLC issued the aforementioned guiding opinion regarding prevention of wrongful convictions. ${ }^{116}$ At the end of the opinion, Article 15 stipulated that PPLCs shall not co-ordinate cases of unclear facts and insufficient evidence and that, when co-ordination is justified and conducted, the PPLC shall not, in normal circumstances, provide specific opinions regarding the decisions on the characterization and substantive issues of the case. ${ }^{117}$ In another occasion, Meng Jianzhu, the new director the CPPLC, also advised local PPLC leaders not to "send instructions [to judges] regarding decisions on individual cases" so that judicial institutions "can do their job without hindrance."118 The SPC capitalized on that momentum and issued an opinion, prohibiting courts from participating in joint case-handling practices with the procuratorate and the police. ${ }^{119}$

However, according to the CPPLC's opinion, the requirement that co-ordination instructions should not involve specific opinions regarding the characterization and substantive

110. For an overview of some of these wrongful conviction cases, see Lewis (2010).

111. Ye, supra note 64; Qian (2014).

112. $\mathrm{Li}(2010)$.

113. Guanyu dangwei Zhengfa Weiyuanhui Dui Zhengfa Bumen Zhifa Huodong Jinxing Jiandu De guiding [Rules on Party Political-Legal Committees' Supervisory Activities over Law Enforcement Activities of Political-Legal Institutions] jointly issued by the CPPLC, CCDI, COD, and central political-legal institutions in 2011; Zhongyang zhengfawei ganyu dangwei Zhengfa Weiyuanhui Dui Zhengfa Bumen Zhifa Huodong Jinxing Jiandu De shishi xize [Operational Manual on Party Political-Legal Committees' Supervisory Activities over Law Enforcement Activities of Political-Legal Institutions] issued by Qinghai Province PPLC in 2012.

114. Hunan sheng zhengfawei anjian duban xietiao gongzuo zhidu [Rules on Case Supervision and Coordination] issued by Hunan Provice PPLC.

115. Zhonggong Zhangjiagang shi zhengfa weiyuanhui zhifa jiandu gongzuo shishi banfa [Operational Rules on Supervision over Law Enforcement] issued by Zhangjiagang City PPLC in 2010; Zhonggong huludao shi lianshan quwei zhengfawei zhifa jiandu gongzuo guize [Rules on Supervision over Law Enforcement] issued by Huludao City Lianshan District PPLC in 2011; Guanyu qieshi fangzhi yuanjia cuoan de guiding [Regulation on Preventing Wrongful Conviction Cases in a Reliably and Effective Manner] issued by the CPPLC in 2013.

116. Guanyu qieshi fangzhi yuanjia cuoan de guiding [Regulation on Preventing Wrongful Conviction Cases in a Reliably and Effective Manner] issued by the CPPLC in 2013.

117. Ibid.

118. Qian, supra note 111.

119. Guanyu jianli jianquan fangfan xingshi yuanjiacuoan gongzuo jizhi de yijian [Opinions on the Establishment and Completing the Operating Mechanism to Prevent Wrongful Convictions] issued by the SPC in 2013. 
issues of the case under co-ordination only applies to "normal circumstances."120 Presumably, in unspecified "special circumstances," the PPLCs can still send specific instructions to courts regarding whatever issues of the cases that they are co-ordinating. More importantly, none of the reform efforts mentioned above touches upon the more fundamental issue that has undermined judicial authority and credibility: the issue of the authority of law vis-à-vis the authority of the Party. For example, the current rules have never authorized a PPLC or court to refuse to implement an unwarranted instruction from a superior Party leader.

To summarize, since the Party terminated the individual case-approval practice in the 1980s, it has started to conduct its supervision over judicial affairs in a much more selective fashion. On the one hand, the Party leaves courts with a measure of autonomy to adjudicate cases that bear no threat to the political monopoly of the Party; on the other hand, the Party retains its privileged access to and the authority of decision-making in judicial affairs, which can be invoked in any court and any time. This superior status of the Party over courts has marked the Party's role in dealing with judicial affairs as both paternalistic and dictatorial. It is paternalistic because the Party must provide support to courts to obtain resources and to secure compliance with court decisions from other state institutions that are beyond the reach of courts. It is dictatorial because, when the Party engages in judicial decision-making, its decisions are outcome-oriented without legal reasoning and are not subject to judicial scrutiny. The macro approach allows the Party to make and/or instruct courts to develop judicial policies along the Party lines and instructions that will be non-discriminatively applied to all courts and all cases concerned. The "micro" level enables the Party to instruct, monitor, or scrutinize courts regarding specific decisions of individual cases or categories of cases that attract attention from the Party. The "macro" and "micro" approaches are complementary, the combination of which allows the Party to maximize the effect of its control over judicial affairs with limited monitoring resources.

\section{CONCLUSION: POLITICAL-LEGALISM}

Above in this article, I provided an analytical account of the institutional construct developed by the Party to authorize as well as supervise courts to perform its adjudicative functions. This institutional design can be termed as "political-legalism," which reflects not only the Party's instrumental view of law, but also the measures and institutional infrastructures that are put in place to ensure that the political will of the Party can prevail in the course of administration of law and justice when needed.

Under the political-legalism, the Party retains its supreme authority in the making, interpretation, application, and enforcement of the law through its institutional control over courts and other legal institutions without the need to declare, articulate, and hence limit its prerogatives to a demarcated field over which ordinary law does not apply. With its secured access to the judicial decision-making process, the Party can claim its prerogative as it goes, namely when the associated issue emerges. Such an approach provides the Party with the maximum flexibility so that it can revise and modify its objectives as the circumstances

120. Guanyu qieshi fangzhi yuanjia cuoan de guiding [Regulation on Preventing Wrongful Conviction Cases in a Reliably and Effective Manner] issued by the CPPLC in 2013. 
change. This also means that the Party can afford to indulge courts and judges to enjoy a considerable degree of judicial discretion, making decisions or taking initiatives based on their own interests as long as the outcomes do not sacrifice the Party's interest. The presence of this non-political space does not, however, suggest "judicial autonomy" because the very existence of this space is conditioned upon the fact that courts are deprived of any capacity to behave autonomously vis-à-vis the Party. After all, it is the Party that has the say in what is political and what is not, and whatever the Party decides, courts have to comply.

Thus, the framework of the political-legalism has the features of a stabilized interactive version of the Stockholm syndrome. First, embedded in the Party-state structure, courts are captured by the Party and their activities are confined within the bounds of scripts developed and imposed on them by the Party. Second, courts must rely on the "generosity" of the Party to acquire their life support, including both institutional resources and delegation of authority, to perform their designated functions. Third, the Party, in reverse, also indulges a "free-zone" where courts are allowed to conduct their business with minimal interference from the Party as long as the Party is assured the full authority to determine the perimeters of the "free-zone," to impose rules on it, and to revoke the privilege when necessary. Placed under this framework, the seeming disparities in terms of the political character of courts as mentioned at the beginning of this article will be united because they are merely reflections of different facets of the same institutional construct that courts are put in and cannot break away from.

\section{LIST OF ABBREVIATIONS}

$\begin{array}{ll}\text { CCDI } & \text { Central Party Discipline and Inspection Committee } \\ \text { CCP } & \text { Chinese Communist Party } \\ \text { COD } & \text { Central Party Organizational Department } \\ \text { CPD } & \text { Central Propaganda Department } \\ \text { CPJIR-LSG } & \text { Central Party Judicial Institutional Reform Leading Small Group } \\ \text { CPPL-LSG } & \text { Central Party Political-Legal Leading Small Group } \\ \text { CPPLC } & \text { Central Party Political-Legal Committee } \\ \text { MOJ } & \text { Ministry of Justice } \\ \text { MPS } & \text { Ministry of Public Security } \\ \text { NPC } & \text { National People's Congress } \\ \text { PPLC } & \text { Party Political-Legal Committee } \\ \text { PRC } & \text { People's Republic of China } \\ \text { SPC } & \text { Supreme People's Court } \\ \text { SPP } & \text { Supreme People's Procuratorate }\end{array}$

\section{REFERENCES}

Anonymous (1998) "Zhu Rongji zai basheng(qu) daji zousi he pianhui gongzuo zuotanhui shang qiangdiao zhichu jianding buyi di yanli daji zousi fanzui [Firmly Strike against Smuggling: Zhu Rongji Said at the Eight-Provinces (Districts) Symposium on Striking against the Crimes of Smuggling and Obtaining Foreign Currency by Fraud]," People's Daily, 26 October. 
Anonymous (2011) "zuigaoyuan: zhongda shipin anquan an yifa congzhong panchu [Supreme People's Court: Aggregating Sentences Shall Be Applied to Serious Food Safety Cases]," Xin Jing Bao Newspaper Network, 28 May.

Anonymous (2015) "renmen weishenme huainian qiao shi [Why Do People Commemorate Qiao Shi]," Xinhua News Network, 15 June.

Anonymous (2017) "Zhongguo Weishenme Buneng Shixing Xifang Sifa Duli [Why Western Judicial Independence Cannot Be Adopted in China]," https://www.chinacourt.org/article/detail/2017/01/id/ 2512847.shtml (accessed 10 November 2018).

Brødsgaard, Kjeld Erik (2002) "Institutional Reform and the Bianzhi System in China." China Quarterly 170.

Chen, Baocheng (2012) "Qiao Shi's Talk at the National Political-Legal Work Colloquium on Jan. 19, 1989-Exerpts from Qiao Shi's Book Talking about Democracy and Rule by Law," http://china. caixin.com/2012-06-21/100403122.html (accessed 10 November 2018).

Cui, Min (2012) "Bashi Niandai 'Yanda' De Huigu Yu Fansi [A Review and Reflection on the 'StrikeHard' Campaigns in the 1980s]." yanhuang chunqiu [China through the Ages], no. 5 (2012).

Fu, Yulin, \& Randall Peerenboom (2010) "A New Analytic Framework for Understanding and Promoting Judicial Independence in China," in R. Peerenboom, ed., Judicial Independence in China: Lessons for Global Rule of Law Promotion, New York: Cambridge University Press, 95-133.

He, Xin (2007) "Why Did They Not Take the Disputes? Law, Power, Politics in the Decision-Making of Chinese Courts." 3 International Journal of Law in Context 203-25.

Hou, Meng (2013) '“Dang Yu Zhengfa' Guanxi De Zhangkai-Yi Zhengfa Weiyuanhui Wei Yanjiu Zhongxin [An Explanation of the Relationship between the Party and the Courts-from the Perspective of the Political-Legal Committee]." 2 faxue jia 1-15.

Jin, Chongji (1998) 周恩来传 [A Biography of Zhou Enlai, Vol. 1-4], Beijing: Central Party Literature Press.

Kavass, Igor I., \& Gary I. Christian (1979) "1977 Soviet Constitution: A Historical Comparison.” 12 Vandebilt Journal of Transnational Law 533-662.

Lewis, Margaret K. (2010) "Controlling Abuse to Maintain Control: The Exclusionary Rule in China." 43 New York University Journal of International Law \& Politics 629.

Li, Ji (2017) "The Power Logic of Justice in China." 65 The American Journal of Comparative Law 95-144.

Li, Ling (2010) "Corruption in China's Courts," in R. Peerenboom, ed., Judicial Independence in China: Lessons for Global Rule of Law Promotion, New York: Cambridge University Press, 196-220.

Li, Ling (2012) "The 'Production' of Corruption in China's Courts- the Politics of Judicial DecisionMaking and Its Consequences in a One-Party State." 37 Law \& Social Inquiry 848-77.

Li, Ling (2015) "'Rule of Law' in a Party-State-a Conceptual Interpretive Framework of the Constitutional Reality of China." 2 Asian Journal of Law and Society 93-113.

$\mathrm{Li}$, Zhen (2016) "Mao Zedong zhuchi zhiding zhonghua renmin gongheguo di yibu xianfa [Mao Zedong Taking the Lead to Draft the 1st Constitution of the P.R.C.]," Xiang Chao, 5 September.

Lim, Benjamin Kang (2014) "Special Report-The Power Struggle Behind China's Corruption Crackdown," Reuters, 23 May.

Liu, Fuzhi (2010F) Memoire of Liu Fuzhi, Beijing: Central Wenxian Publishing House.

Liu, Quan'e (2012) "Shanganning Bianqu Sifa Gaige Yu 'Zhengfa Chuantong' De Xingcheng [Judicial Reform in Shanganning Border-Region and the Establishment of the 'Political-Legal Tradition']." Jilin University.

Liu, Wei (2010W) "Ershi Ge Zhongyang Jigou Zhixing Liandong Jizhi Pojie Fayuan Zhixing Nan [Twenty Central Institutions Take Joint Actions to Solve the Obstacles in Enforcing Court Judgments]." minzhu yu fazhi shibao [Democracy and Rule by Law Times], 26 July.

Liu, Zhong (2013) "The Shaping of the Thought of Party Governing Politics and Law in Organization History (1949-1958)." 2 Fa Xuejia [The Jurists] 16-32.

Long, Zongzhi (1997) "Should Prosecutors Stand Up—a Reflection on the Rituals of the Trial." Fa Xue, no. 3. 
Ma, Haiyan (2013) "Dang Shipin Anquan Pai Zai Jingji Fazhan Shouwei [When Food Safety Is Put at the Top of Economic Development Agenda]," http://finance.sina.com.cn/zl/money/20131216/105717646164.shtml (accessed 10 November 2018).

Mao, Zedong (1992) "Dui Zhongyang Jueding Chengli Caijing, Zhengfa, Waishi, Kexue, Wenjiao Ge Xiaozu De Tongzhigao De Piyu He Xiugai [Mao Zedong's Remarks and Edits of the Central Party's Drafted Notice on the Establishment of the Financial, Political-Legal, Foreign Affairs, Science, and Culture and Education Small Groups]," in Mao Zedong's Manuscripts since the Establishment of the P.R.C., Vol. 7, Beijing: Central Archive Publishing House, 268-9.

Miller, Alice (2008) “The CCP Central Committee's Leading Small Groups.” 26 China Leadership Monitor 1-21.

Minzner, Carl (2011) "China's Turn against Law." 59 American Journal of Comparative Law 935-84.

Ng, Kwai Hang, \& Xin He (2017) Embedded Courts: Judicial Decision-Making in China, Cambridge: Cambridge University Press.

Party Congress Database (1958) "Summary of the 5th Plenary Session of the 8th Central Party Committee," Online Archive, http://cpc.people.com.cn/GB/64162/64168/64560/65348/4442051.html (accessed 10 November 2018).

Peng, Zhen (1992a) Lun Xin Zhongguo De Zhengfa Gongzuo [On the Political-Legal Work in New China], Beijing: Renmin Publishing House.

Peng, Zhen (1992b) "Summarized Scripts of the Speech at the First Meeting of the Central PoliticalLegal Committee," in Z. Peng, ed., Lun Xinzhongguo De Zhengfa Gongzuo [On the Political-Legal Work of New China], Beijing: Central Wenxian Publishing House, 216-7.

Qian, Haoping (2012) "How Does the 'Leading Small-Group' Lead?" Nanfang Renwu Weekly, 5 September.

Qian, Haoping (2014) "Zhengfawei Zhuanxing Zhe Yinian [The Year of Transition for Party PoliticalLegal Committees]," nanfang zhoumo [Southern Weekend], 17 January.

Qin, Xudong (2014) "Zhongyang Sifa Tizhi Gaige Lingdao Xiaozu Jiexi [An Illustration of the Central Judicial Institutional Reform Leading Small-Group]," Caixin Network, 19 January.

Shao, Zonghai (2005) "Defining the Institutional Role of the Central Party Small Leading Groups." 48 Mainland Research 1-24.

Special Report (2014) "How Do 'Small-Groups' Goven a Big Country?" 1154 dianji jinri, Online archive, from Sohu News Portal. http://news.sohu.com/s2013/dianji-1154/ (accessed 22 February 2019).

Xinhua News (2012) "Zhou Yongkang: Full Implementation of All Judical Institutional Reform Measures," Xinhua News, 20 January.

Yang, Xiancheng (2013) "Zalan Gongjianfa He Qingli Jieji Duiwu [Destroying Publis Security Organs, Courts and Procuratorates and Purging Classes]." 2 yanhuang chunqiu [China through the Ages] 55-8.

Ye, Zhusheng (2014) "Zhengfawei Xietiaohui Jizhi Mianlin Gaige [Political-Legal Committee Coordinating Meeting Mechanism Faces Change]," Nan Feng Chuang, 9 May.

Yu, Hao (2013) "Sifa Jieshi 'Shoushen' Chenggong [Successful 'Shrink' of Judicial Interpretations]." 9 China's People's Congress Journal 32-5.

Zhang, Taisu (2012) "The Pragmatic Court: Reinterpreting the Superme People's Court of China." 25 Columbia Journal of Asian Law 1-61.

Zhong, Jinyan (2012) "Zhengfawei Lishi Yu Yanbian De Zai Sikao [A Revisit to the History and Vicissitude of the Political-Legal Committee]." 12 yanhuang chunqiu [China through the Ages] 50-6.

Zhou, Yongkun (2012) "Zhengfawei De Lishi Yu Yanbian [The History and Vicissitude of the PoliticalLegal Committee]." 9 yanhuang chunqiu [China through the Ages] 7-14.

Zhu, Suli (2010) "The Party and the Courts," in R. Peerenboom, ed., Judicial Independence in China: Lessons for Global Rule of Law Promotion, New York: Cambridge University Press, 52-68. 